\title{
Negative responses of highland pines to anthropogenic activities in inland Spain: a palaeoecological perspective
}

\author{
Juan M. Rubiales • César Morales-Molino • \\ Salvia García Álvarez • Mercedes García-Antón
}

\begin{abstract}
Palaeoecological evidence indicates that highland pines were dominant in extensive areas of the mountains of Central and Northern Iberia during the first half of the Holocene. However, following several millennia of anthropogenic pressure, their natural ranges are now severely reduced. Although pines have been frequently viewed as first-stage successional species responding positively to human disturbance, some recent palaeobotanical work has proposed fire disturbance and human deforestation as the main drivers of this vegetation turnover. To assess the strength of the evidence for this hypothesis and to identify other possible explanations for this scenario, we review the available information on past vegetation change in the mountains of northern inland Iberia. We have chosen data from several sites that offer good chronological control, including palynological records with microscopic charcoal data and sites with plant macro- and megafossil occurrence. We conclude that although the available longterm data are still fragmentary and that new methods are needed for a better understanding of the ecological history of Iberia, fire events and human activities (probably
\end{abstract}

\footnotetext{
J. M. Rubiales (匈) - C. Morales-Molino - S. García Álvarez Departamento de Silvopascicultura, Escuela de Ingeniería Forestal y del Medio Natural, Universidad Politécnica de Madrid, Ciudad Universitaria, s/n, 28040 Madrid, Spain e-mail: jm.rubiales@upm.es

C. Morales-Molino · M. García-Antón

Departamento de Biología (Botánica), Facultad de Ciencias, Universidad Autónoma de Madrid, C/Darwin 2, 28049 Madrid, Spain
}

modulated by climate) have triggered the pine demise at different locations and different temporal scales. In addition, all palaeoxylological, palynological and charcoal results obtained so far are fully compatible with a rapid human-induced ecological change that could have caused a range contraction of highland pines in western Iberia.

Keywords Iberian Peninsula - Holocene . Palaeoecology $\cdot$ Human impact $\cdot$ Fire $\cdot$ Pinus

\section{Introduction}

A common generalisation, found extensively in the scientific literature, is that pines are linked evolutionarily and ecologically to disturbance (e.g. Mirov 1967; Richardson and Rundel 1998). Indeed, many pine species are frequently described as pioneers and are known to have advantages over other tree taxa under low to severe disturbance regimes, including fire, clearance and windthrow (Richardson et al. 2007). Pines are generally classified as shade-intolerant species whose seedling performance and high photosynthetic rates allow them to grow and to establish themselves rapidly. At a longer timescale, pine forests persistence is frequently explained by the occurrence of disturbance events, among which fire has received particular attention (Naveh 1975; Agee 1998; Barbero et al. 1998; Pausas et al. 2006; Verdú and Pausas 2007; Tapias et al. 2004).

The Mediterranean region is probably the part of the world that reveals the longest and most evident history of interactions between pine forests and human activities (Le Maitre 1998). The understanding of the effects of disturbances over time has become a central issue in biogeography, owing to its important implications for management and nature conservation (e.g. Willis and Bhagwat 2010). In 
a review with a specific focus on pinewoods, Richardson et al. (2007) examined the positive and negative impacts of human activities on the distribution and abundance of the genus Pinus worldwide and showed that most of the alterations of the natural dynamics of pine forests (other than the direct use of wood or nuts) are related to changes in fire regimes and browsing. However, the environmental heterogeneity of the Mediterranean area produces contrasting vegetation types and responses over time throughout the region (e.g. Carrión et al. 2010), and the existence of common patterns in the inland mountains of the Iberian Peninsula, the focus of this paper, remains poorly investigated. Here, we provide some examples, based on published data on pollen, microscopic charcoal, and plant macro- and megafossil data, which suggest that anthropogenic activities and fire during historic times (roughly, the last three millennia) have been the main drivers of the more severe changes in vegetation during the second half of the Holocene. These main drivers are responsible for contractions in the range of mountain pines and for local to regional extinctions of mountain pine forests.

\section{Geographical setting}

The geographical scope of this study is restricted to certain mountain ranges in inland Central and Northern Spain that share notable biogeographic characteristics (Fig. 1). These mountains surround the Iberian Central Plateau, which constitutes a larger geographic unit within the Iberian Peninsula. Towards the north, the Cantabrian Range and adjacent mountains (e.g. Ancares Mountains, Teleno Mountains) are aligned in a prevailing latitudinal direction (i.e. east to west). The greatest altitudes in this area are represented by Peña Ubiña $(2,417 \mathrm{~m}$ a.s.1.) in the west and Torre Cerredo (2,648 m. a.s.l.) in Picos de Europa. Palaeozoic siliceous bedrock predominates towards the western part of the Cordillera (including shales, sandstone, schist and quartzite), whereas limestones tend to predominate towards the east. Contrasting physiography (from hilly land to sharp relief) is present throughout the area.

At the northeastern boundary of the plateau, an area of lower altitudes extends as a transition between the Cantabrian Range and other important ranges (i.e. the Pyrenees and the Iberian System). The Iberian System bounds the Central Plateau on the east and runs primarily in a northwest to southeast direction. Although the highest peaks rarely reach more than 2,200 $\mathrm{m}$ a.s.l., the range itself shows a high degree of complexity and reaches massive proportions towards the south. Limestones are predominant in this zone, although siliceous bedrock is characteristic of some sectors (e.g. the Demanda Mountains, the Albarracín Mountains).

A third range, the Central Mountain Range, divides the Central Plateau into two separate units. This range is composed of several siliceous (granites and gneisses) mountain units (i.e., the Ayllón, Guadarrama, Gredos, Peña de Francia and Estrela Mountains). The largest part of the
Fig. 1 Map of the sites listed in the text: 1 Xan de Llamas (Morales-Molino et al. 2011), 2 Lillo (García-Antón et al. 1997), 3 Pardillas Lake (Sánchez-Goñi and Hannon 1999), 4 Ojos del Tremedal (Stevenson 2000), 5 Pelagallinas (Franco Múgica et al. 2001), 6 Serranillos (López-Merino et al. 2009)

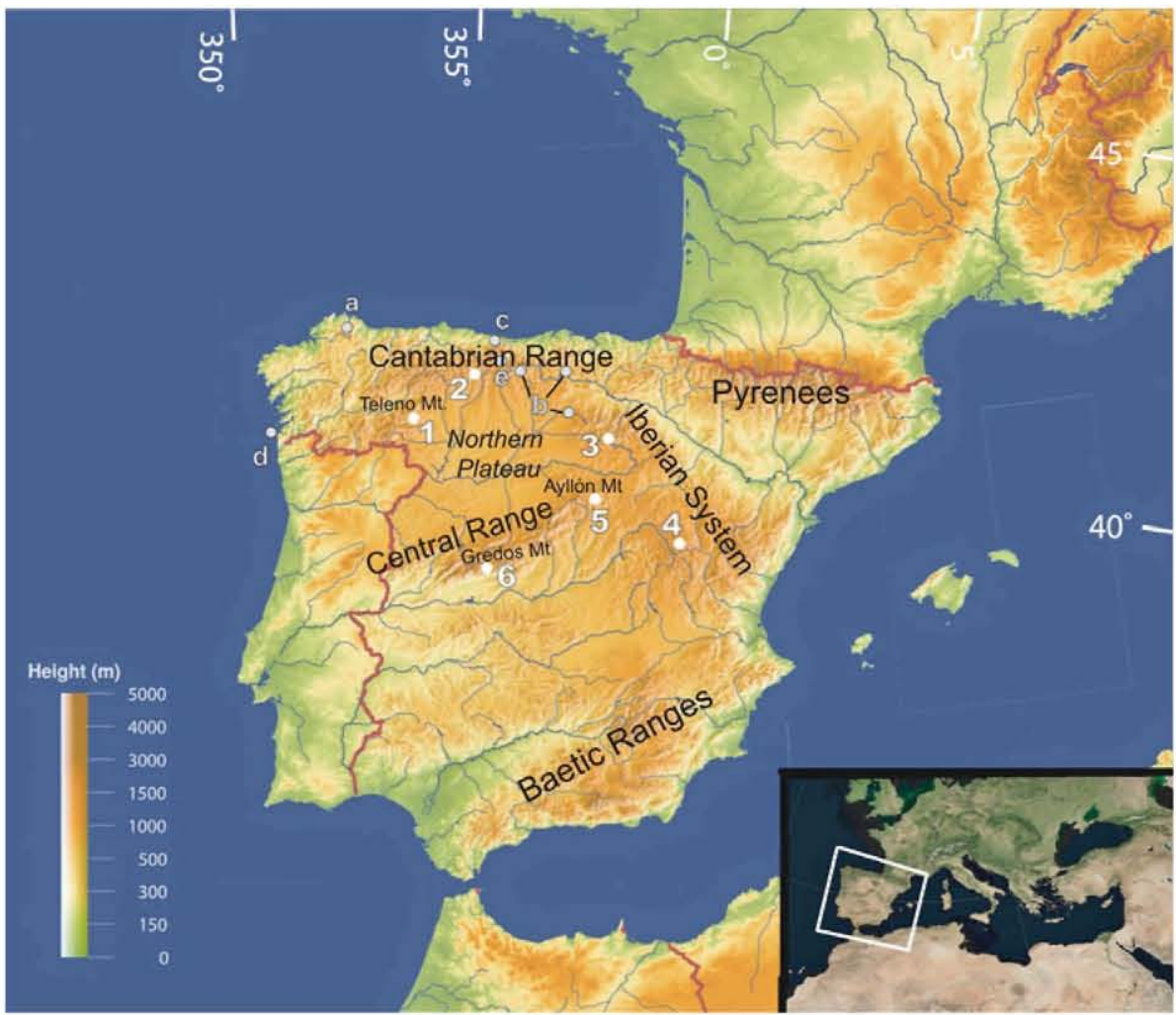


range (the Gredos Mountains), which is nearly $50 \mathrm{~km}$ wide, also includes the highest peaks (Almanzor, 2,592 m a.s.1.). The highest altitudes in these mountains generally exhibit a smooth orography.

Although climatic nuances are found in each mountain range, the ranges all share some common climatic features. The climate is subcontinental Mediterranean, with the mean annual precipitation varying between approximately 700 and $1,200 \mathrm{~mm}$ and $2-3$ months of summer drought. Sharp temperature variations occur, especially in the mountains situated in the inner parts of the Peninsula (Iberian System, Gredos Mountains). Nevertheless, the western and northern slopes of the Cantabrian Range show a more oceanic, temperate climate and greater precipitation than the rest of the study area.

The arboreal vegetation in the area is dominated by both deciduous and evergreen species. At the lower altitudes of the mountains, submediterranean Quercus $(Q$. pyrenaica Willd. on the siliceous substrates and $Q$. faginea Lam. on both siliceous and calcareous soils, but more frequent on the latter) usually dominate the forests. Frequently associated with Quercus, but becoming dominant at higher altitudes, pinewoods dominated by Pinus sylvestris L., P. nigra J.F. Arnold or $P$. pinaster Aiton are often found in the central and eastern areas of the Central Mountain Range and the whole Iberian System. However, these forests are almost completely absent from the western mountains (excluding some small stands and recent afforestations). In mesic and more oceanic areas, other species of the genus Quercus $(Q$. petraea (Matt.) Liebl. and Q. robur L.), beech forests (Fagus sylvatica L.) and birch stands (Betula pubescens Ehrh.) appear. A number of other mesophytic deciduous species (e.g. Corylus avellana L., Acer pseudoplatanus L. or Fraxinus excelsior L.) are found in mixed stands with the abovementioned trees on well-developed soils. After intense forest clearance or disturbance, shrub communities mainly composed of Ericaceae, Fabaceae and Cistaceae with an herbaceous layer dominated by Poaceae become the dominant vegetation in the landscape.

In this paper, we focus on the response of the group of Iberian highland pines (Fig. 2), which comprises Pinus uncinata Ramond ex DC., P. sylvestris L. and P. nigra J.F. Arnold subsp. salzmannii (Dunal) Franco, to humaninduced disturbances during the late-Holocene. Pinus uncinata is currently distributed all over the Pyrenean Range, where it usually dominates the high montane and subalpine forests, and it occurs in two small isolated and relict populations located in the Iberian System. Pinus sylvestris is presently abundant in the mountainous areas of northeastern Iberia (Pyrenees, Iberian System, Guadarrama Mountains). In addition to these extensive pinewoods, several relict stands occur in northern and northwestern Iberia (e.g. Lillo, Velilla del Río Carrión and Serra do Gerès), the Gredos Mountains, and the Baetic Ranges (i.e.
Fig. 2 The distribution of the two most widespread pine species in the mountains of Iberia (blue: Pinus sylvestris, light green: Pinus nigra; source: EUFORGEN network, http://www.euforgen.org/ distribution_maps.html). Relict stands and small populations are represented by square dots. The locations of areas with studied pine macro- and megafossils are represented by ellipses. $a$ Teleno Mountains (Morales-Molino et al. 2011; unpublished data). $b$ Cantabrian Mountains (Sánchez Hernando et al., 1999; Rubiales et al. 2008, unpublished). $c$ Tubilla del Lago and Tubilla del Agua (García-Amorena et al. 2011). $d$ Sierra de Gredos (Rubiales et al. 2007)

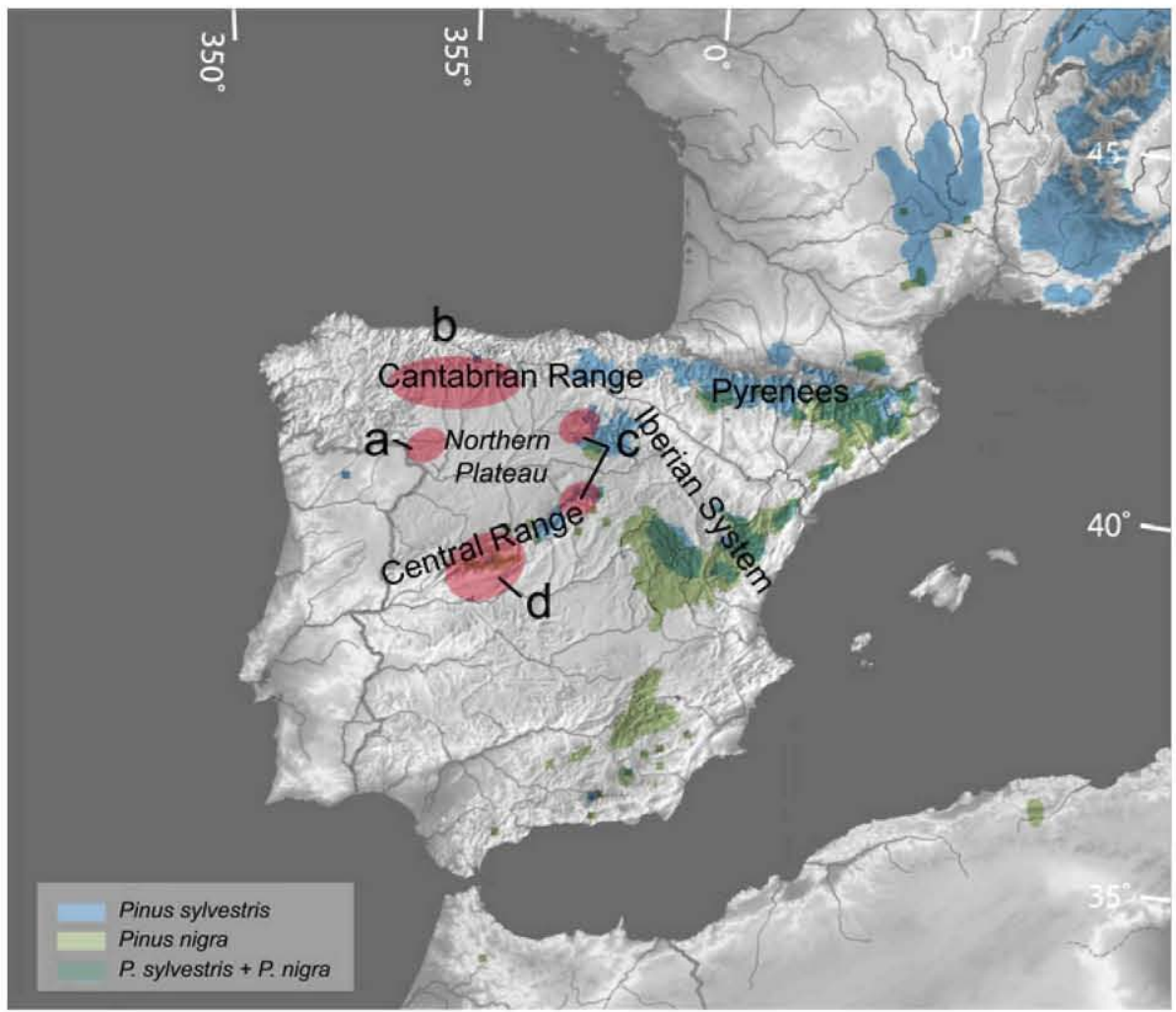


Cazorla and Sierra Nevada-the southernmost population in its entire area of distribution). P. nigra subsp. salzmannii covers extensive areas in the Pyrenees and the Iberian and Baetic Ranges, with relict populations occurring in the Central Mountain Range (the Gredos and Guadarrama Mountains).

\section{Palaeoecological evidence and methodological considerations}

Here, we analyse palynological information documenting the evolution of the late-Holocene vegetation in mountain areas. The aim of this analysis is to detect the response of pinewoods, using complementary information indicative of plant macro- and megafossil occurrence and using microscopic charcoal data that furnish evidence of trends in fire activity at the regional scale. Six pollen sites (Table 1) have attracted considerable interest, owing primarily to their good chronological control during the last half of the Holocene and the complementary information on charcoal that they provide. The dynamics of the vegetation will be reconstructed from the pollen diagrams. These reconstructions will focus on pollen indicators, including those of the most important tree species, shrubs characteristic of degraded woodlands and other anthropogenic indicators. The pollen types represented in the anthropogenic indicators curve include Olea, Castanea, Juglans, Vitis, Cerealia- type, Rumex, Plantago (several pollen types) and Urtica, following the criteria in Carrión et al. (2010). The curves designated "other mesophytes" include the following genera: Ilex, Alnus, Corylus, Sambucus, Viburnum, Fagus, Fraxinus, Tilia, Salix, Ulmus, Populus, Acer, Ligustrum, Frangula and Rhamnus.

In this study, particular reference is made to the highland pines. However, it has to be kept in mind that the differentiation of the related species by means of pollen analyses is not possible (with the occasional exception of part of the pollen spectra of $P$. pinaster, Carrión et al. 2000). Plant macrofossils (such as wood or cones) can be used as complementary information for interpreting pollen data (Fig. 2) because this palaeoenvironmental data source allows the positive detection of tree taxa over time. Beyond these taxonomic implications, the relatively well-known origin of macro- and megafossils serves to provide more detailed definition of the zones in which these species lived in the past. Consequently, zones with plant macrofossil occurrence (Table 2; Fig. 2) will also be used to interpret the pollen data.

Currently, only wood remains of Pinus sylvestris (and infrequent data suggesting the occurrence of $P$. uncinata, e.g. Hannon 1985) have been identified within the Holocene vegetal history of the western area. In the Iberian System and the eastern part of the Northern Plateau, macroremains of $P$. nigra have been also reported (e.g. García-Amorena et al. 2011).

Table 1 Selected palaeoecological sites with well dated late-Holocene microcharcoal data

\begin{tabular}{lllll}
\hline Site & Location & Coordinates & Chronology (cal. yr B.P.) & References \\
\hline Xan de Llamas & Teleno Mountains & $42^{\circ} 18^{\prime} \mathrm{N} 6^{\circ} 19^{\prime} \mathrm{W}$ & ca. 4500-present & Morales-Molino et al. (2011) \\
Lillo & Cantabrian Range & $43^{\circ} 00^{\prime} \mathrm{N} 5^{\circ} 16^{\prime} \mathrm{W}$ & 1800 -present & García-Antón et al. (1997) \\
Pardillas Lake & Northern Iberian System & $42^{\circ} 2^{\prime} \mathrm{N} 3^{\circ} 2^{\prime} \mathrm{W}$ & ca. 12000-present & Sánchez Goñi and Hannon (1999) \\
Ojos del Tremedal & Southern Iberian System & $40^{\circ} 32^{\prime} \mathrm{N} 2^{\circ} 2^{\prime} \mathrm{W}$ & ca. 9600-440 & Stevenson (2000) \\
Pelagallinas & Ayllón Mountains & $41^{\circ} 11^{\prime} \mathrm{N} \mathrm{3} 4^{\prime} \mathrm{W}$ & ca. 4300-present & Franco Múgica et al. (2001) \\
Serranillos & Gredos Mountains & $40^{\circ} 18^{\prime} \mathrm{N} 4^{\circ} 56^{\prime} \mathrm{W}$ & ca. 2000-present & López-Merino et al. (2009) \\
\hline
\end{tabular}

Table 2 Geographic areas with dated macro- and megafossils of Pinus gr sylvestris corresponding to the late-Holocene

\begin{tabular}{|c|c|c|c|c|}
\hline Area & Locations & $\begin{array}{l}\text { Number } \\
\text { of sites }\end{array}$ & $\begin{array}{l}\text { Age } \\
\text { (cal. yr B.P.) }\end{array}$ & References \\
\hline Teleno Mountains & $\begin{array}{l}\text { Pobladura de la Sierra, Xan de } \\
\text { Llamas (León) }\end{array}$ & 2 & ca. 3000 & $\begin{array}{l}\text { Morales-Molino et al. (2011; } \\
\text { unpubl.) }\end{array}$ \\
\hline $\begin{array}{l}\text { Western and Central } \\
\text { Cantabrian Range }\end{array}$ & Babia, Laciana, Alto Porma (León) & 14 & ca. $9000-1400$ & $\begin{array}{l}\text { García-Antón et al. (1997); } \\
\text { Sánchez Hernando et al. (1999); } \\
\text { Rubiales et al. (2008; unpubl.) }\end{array}$ \\
\hline $\begin{array}{l}\text { Eastern part of the } \\
\text { Northern Meseta }\end{array}$ & $\begin{array}{l}\text { Tubilla del Agua, Tubilla del } \\
\text { Lago, Fuentetoba (Burgos and } \\
\text { Soria) }\end{array}$ & 3 & ca. $9000-1300$ & García-Amorena et al. (2011) \\
\hline Central Range & Sierra de Gredos (Ávila) & $>30$ & ca. $6500-900$ & Rubiales et al. (2007; unpubl.) \\
\hline
\end{tabular}




\section{Results and discussion}

Holocene vegetation history inferred from pollen and from plant macro- and megafossil data

Although the temporal coverage and the resolution of the pollen records available from the highlands of central Spain differ significantly, most of these records show a phase of dominance or co-dominance of pine woodlands during the early and/or mid-Holocene (Rubiales et al. 2010; Carrión et al. 2010; Pérez-Obiol et al. 2011). In the Atlantic areas of Iberia, the most common postglacial vegetation trend consists of a temporal succession during which the distribution of broad-leaved trees expands and pinewoods regress. However, the pinewoods in inland Spain have behaved as dominant and resistant communities across millennia. This last-cited pattern has been reported largely from the Northern Iberian Plateau (García-Antón et al. 2011) under a genuine Mediterranean climate, but it also occurs in some of the surrounding mountains that form the geographical focus of this paper. Despite the differences in climate and vegetation between the lowlands and the surrounding mountains (where the climate is cooler and wetter), pinewoods have also persisted in these highlands since the Late Glacial, and the palaeoenvironmental records show little or no evidence of vegetation turnover prior to the intensification of anthropogenic activity (Rubiales et al.
2010). However, primarily because the Iberian territory has extraordinarily diverse climates, physiography and substrates, the "starting points" for the post-glacial recovery and the vegetation responses were not homogeneous. Thus pinewoods were commonly accompanied by different deciduous trees during the early to mid-Holocene (e.g. Betula, Quercus, other mesophilous species). During the mid- to late Holocene, all of the reported sites show different patterns of pinewood regression, as we will discuss below for each location.

The Xan de Llamas peat bog sequence (Morales-Molino et al. 2011) records the dynamics of the vegetation in the highlands of the Teleno Mountains during the last $4000-4500$ cal. yr B.P. (Figs. 1, 3). From the beginning of the sequence until ca. 3300-3200 cal. yr B.P., this area was covered by pine- and birch-dominated forests with an Ericaceae-rich understory. A clear minor increase in microscopic charcoal is found after ca. 3200 cal. yr B.P. This feature coincides with a lithologic change to highly inorganic sediment (indicative of an erosive event) and a sharp decrease in pollen concentration (Morales-Molino et al. 2011). Similarly, anthropogenic indicators also exhibit a weak increase. At the same time, the forests show an abrupt decline and are replaced by grasslands and heathlands. Increased human activity (fire and grazing as well as logging and mining activities or a combination of any of them) could be the cause of this abrupt deforestation process.
Fig. 3 Synthetic pollen diagram from Xan de Llamas, redrawn from Morales-Molino et al. (2011). Exaggeration $\times 10$. Lithology: 1 Peat with abundant roots. 2 Peat with wood fragments. 3 Clayey peat. 4 Silty clay. 5 Silty clay with charcoal fragments

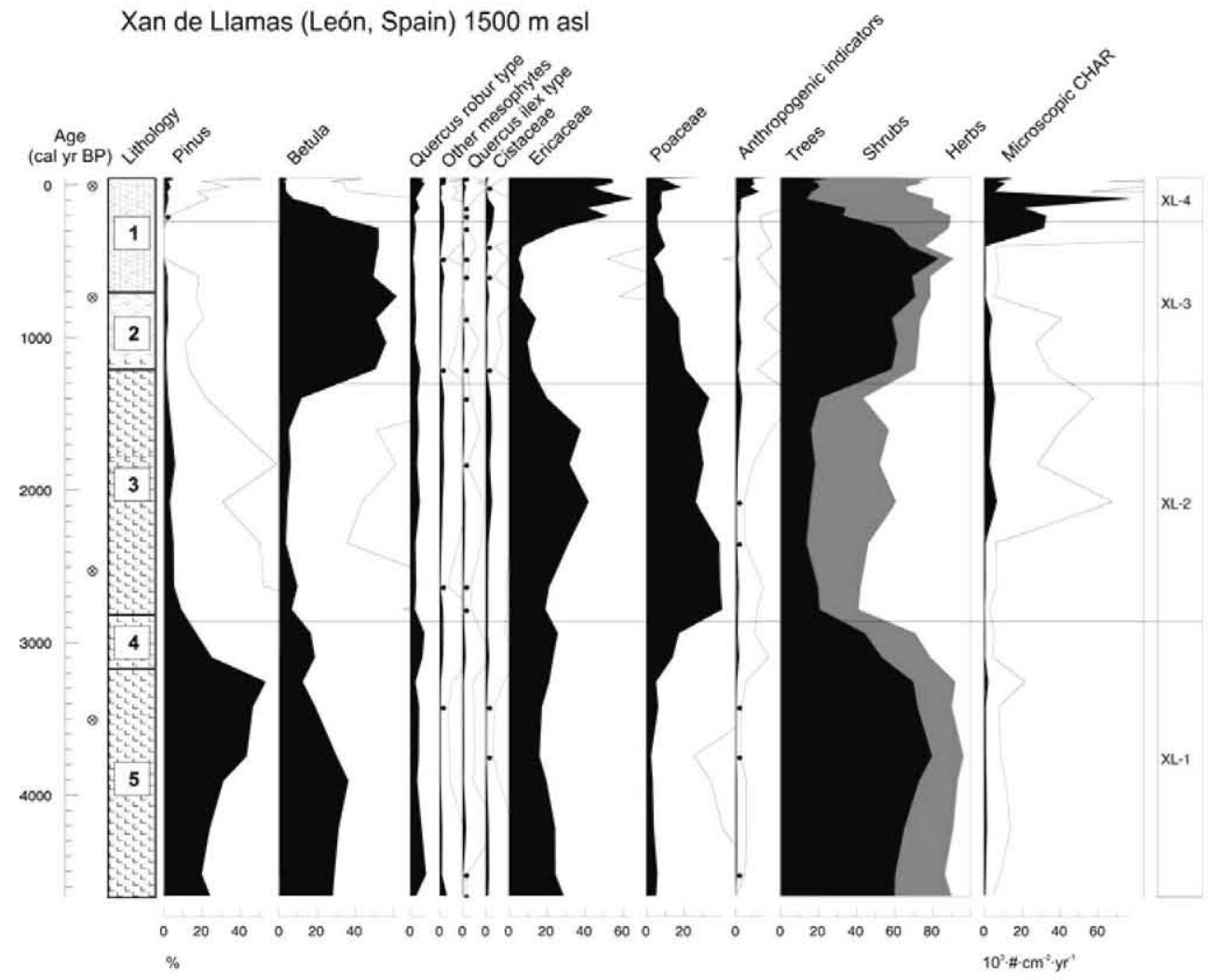


Fig. 4 Synthetic pollen diagram from Lillo, redrawn from García-Antón et al. (1997). Exaggeration $\times 10$. Lithology: Peat

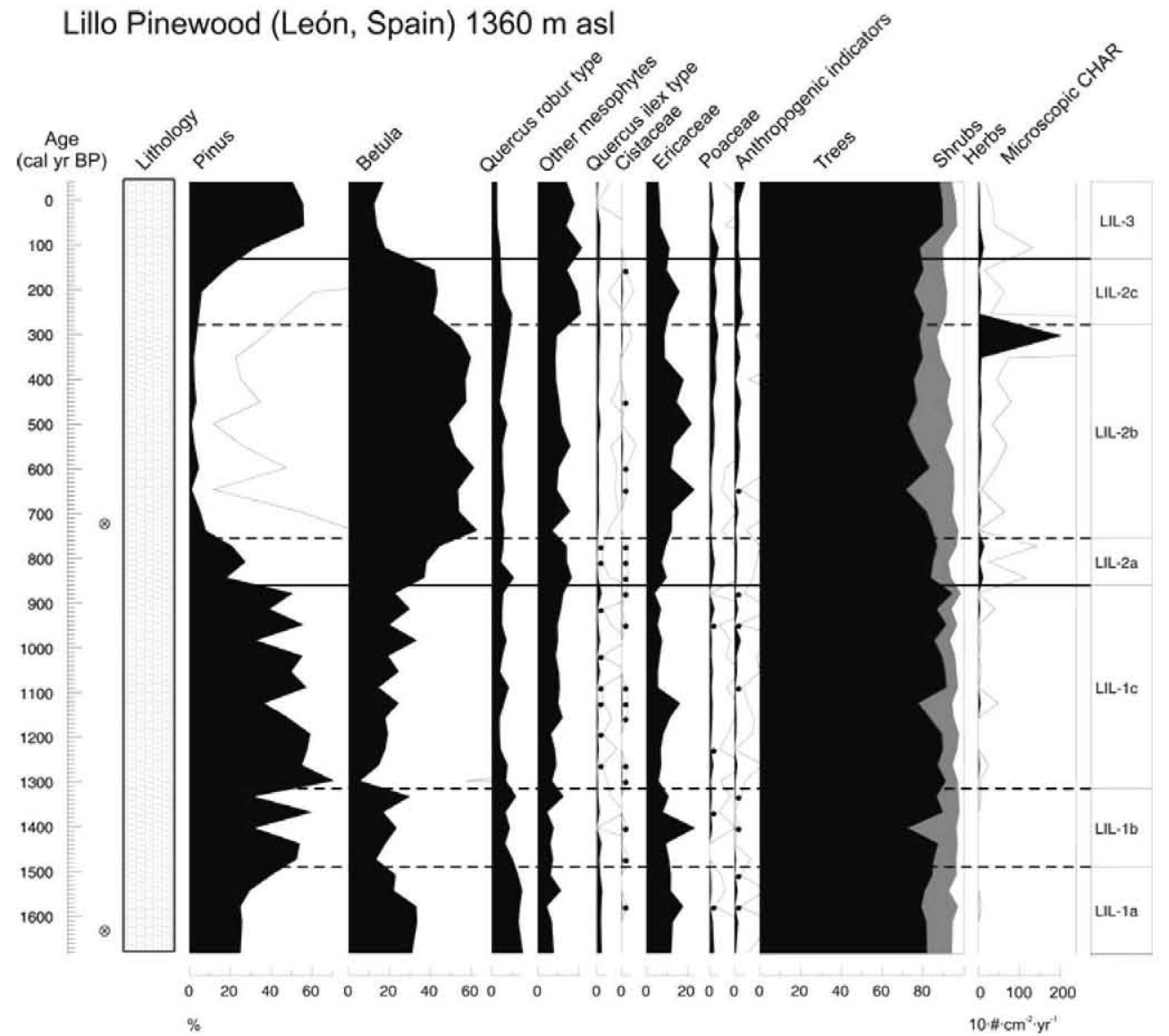

Subsequently, this open vegetation dominated the landscape until ca. $1300 \mathrm{cal}$. yr B.P., when the Betula pollen curve shows a significant increase. This event probably marks the human abandonment of the highland areas. Finally, a strong increase in the regional activity at ca. $300 \mathrm{cal}$. yr в.P. is linked to the disruption of the birch forests. These forests were replaced by heathlands, presently the dominant vegetation community in the mountains of NW Iberia.

The pollen sequence from the Lillo Pinewood (GarcíaAntón et al. 1997) furnishes information about the vegetation dynamics in the central part of the Cantabrian Range during the last two millennia (Figs. 1, 4). This site is especially interesting because it is located in one of the very few relict stands in this mountainous area that are currently dominated by $P$. sylvestris. This sequence starts at ca. $1700 \mathrm{cal}$. yr B.P. and is characterised by the presence of a forested landscape throughout the record. Until ca. $850 \mathrm{cal}$. yr B.P., Pinus and Betula dominated the composition of the forests surrounding the site. At this point, Pinus was replaced by Betula in association with a detectable increase in regional fire activity and a higher representation of Ericaceae. The cause of this change in the composition of the forest could be pine logging by local human populations and/or the use of fire to clear the forest.
The openings created by these activities could be colonised easily by a pioneer tree like Betula. This birch-dominated period ended in ca. $200 \mathrm{cal}$. yr B.P., when an extremely large peak in the microcharcoal curve occurred and pines resumed their dominance of the forest vegetation. Other mesophytes (primarily Fagus) continued to increase their importance in the regional landscape.

The pollen record from Las Pardillas Lake (Fig. 1) shows a relatively stable distribution of the vegetation types throughout the sequence (Sánchez Goñi and Hannon 1999). This record documents the expansion of deciduous taxa (e.g. Quercus, Corylus, Ulmus, Fraxinus, Fagus) since approximately $9000 \mathrm{cal}$. yr в.P. Nevertheless, Pinus is the most frequent taxon throughout the whole record, with percentages that almost always exceed 50\%. The lack of important changes in the vegetation during the first half of the Holocene seems to be the result of a relatively stable climate. In the last part of the sequence (from approximately $2300 \mathrm{cal}$. yr B.P. onwards), the arboreal taxa, with the sole exception of Fagus, show a decline that seems synchronic with the stabilisation of the curve of Olea and Cerealia. This decline corresponds with maxima in the macroscopic charcoal curve (both in macroscopic charcoal particle accumulation rate and in concentration). The coupled increase in charcoal concentrations, Olea and other 
Fig. 5 Synthetic pollen diagram from Pelagallinas, redrawn from Franco Múgica et al. (2001). Exaggeration $\times 10$. Lithology: Peat

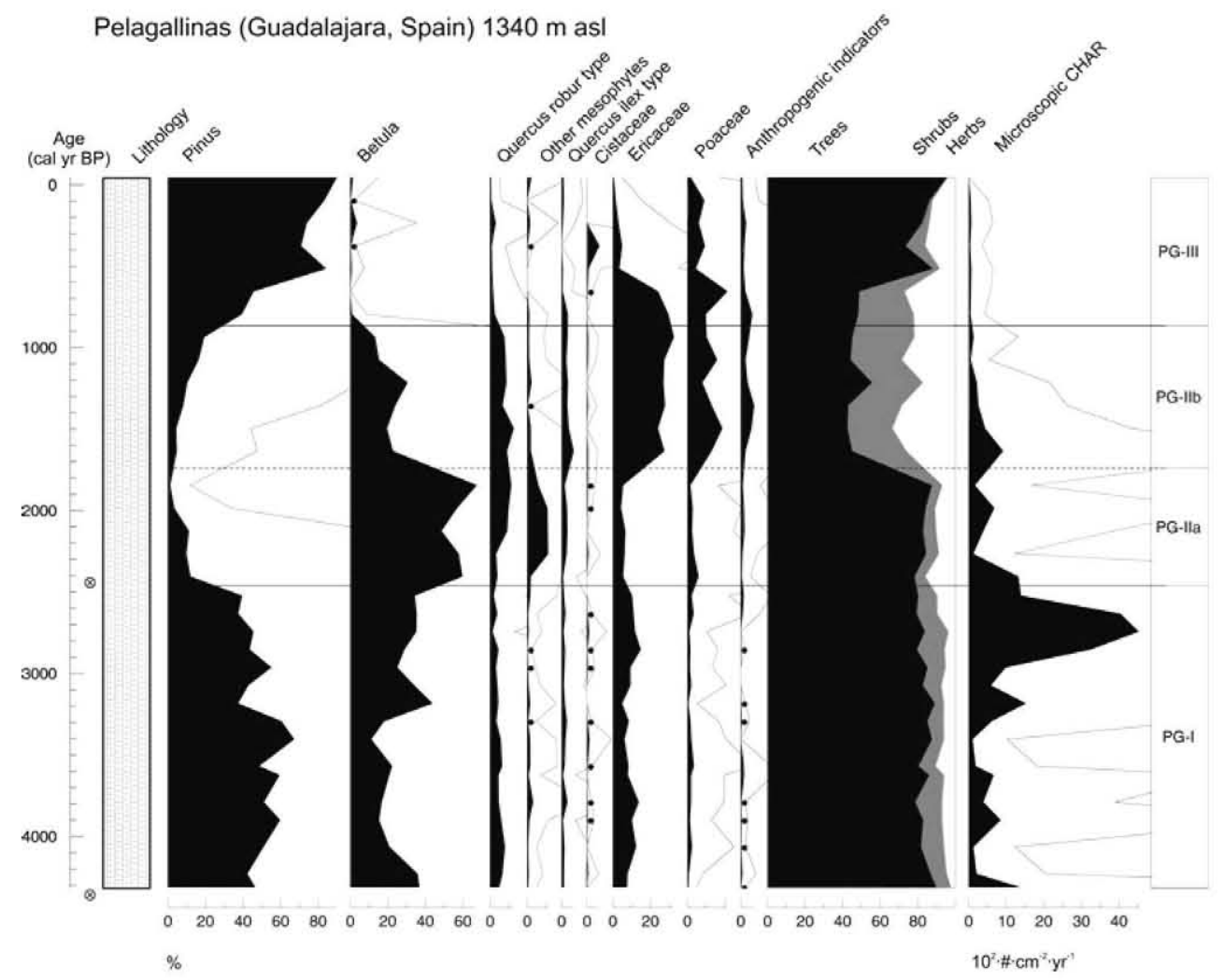

palynological indicators of human activities (Plantago, Rumex, Poaceae) suggests that the most important change in the sequence results from increased anthropogenic activity, which continued to grow in intensity during the Roman period.

The palaeoecological information from Ojos del Tremedal (Fig. 1) shows that since the early Holocene (ca. 9500 cal. yr B.P.), Pinus and Betula appear to have played the most important role in the forest vegetation of the region (Stevenson 2000). The Betula decline occurs at approximately $6500 \mathrm{cal}$. yr B.P. Thereafter, Pinus remains the major forest species in the region until the top of the sequence (ca. 440 cal. yr в.P.). However, several significant regressions of pinewoods are recorded during the midHolocene. All three events are associated with peaks in the microscopic charcoal record. This finding suggests that fire events could have been the major drivers of these changes in pine abundance. The first decline, occurring at ca. $6 \mathrm{ka}$, is also linked with small peaks of Corylus and Salix. The second decline of pines (ca. $5 \mathrm{ka}$ ) is related to a sharp increase in Plantago and Poaceae, suggesting a greater openness in vegetation. During the last pine decline, occurring at approximately $4 \mathrm{ka}$, Betula appears to have been favoured over Pinus and shows a small peak in its pollen curve. This last event seems to have triggered a period of instability, during which shrublands (mainly composed of Cistus and Ericaceae) and grasslands clearly expanded. Finally, at the uppermost part of the pollen diagram, some pollen types that are usually considered as indicators of anthropogenic activities (e.g. Plantago and Fabaceae) show a notable increase, which is probably associated with human-induced disturbances.

The Pelagallinas sequence (Figs. 1,5) shows a birch- and pine-dominated forest covering the vicinity of the peat bog from ca. 4300 to ca. 2500 cal. yr B.P., with some Ericaceae present in the understory (Franco Múgica et al. 2001). An important increase in regional fire activity is recorded by the microscopic charcoal curve at ca. $2900 \mathrm{cal}$. yr B.P. and reaches a maximum at ca. $2600 \mathrm{cal}$. yr B.P. Following this period of higher fire activity, approximately 2500 cal. yr B.P., Pinus is replaced by Betula. However, the charcoal increase occurs approximately one hundred years before the pine decline. This discordance could have been caused by differences in the pollen and charcoal source areas and may reflect the burning of lowland forests prior to those near the Pelagallinas site. The pollen record does not show increases in anthropogenic indicators and Ericaceae or clear signs of deforestation around the site. At the start of the following pollen subzone (PG-IIb, ca. $1800 \mathrm{cal}$. yr B.P.), a clear decline in the arboreal pollen percentages is associated with significant increases in Ericaceae, anthropogenic indicators and a relative maximum in the microscopic charcoal curve. A remarkable increase in the representation of the deciduous Quercus (probably Q. pyrenaica) occurs during this 


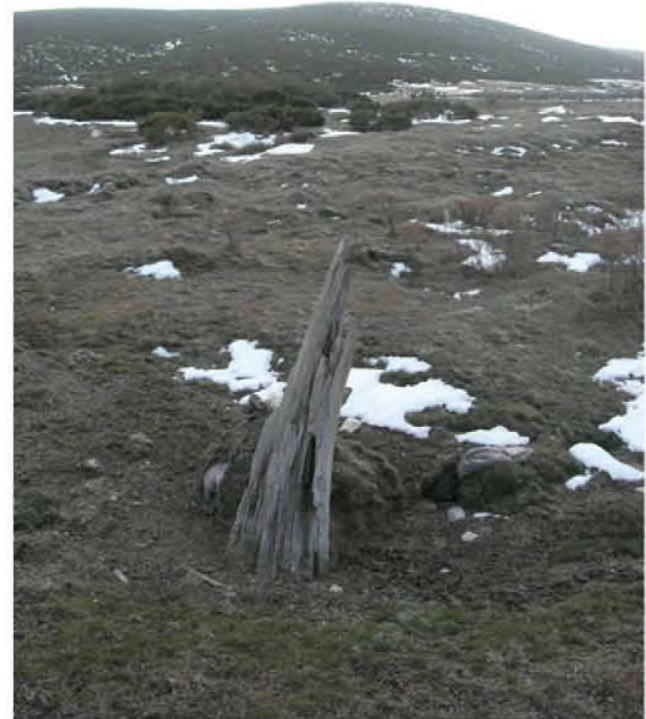

Fig. 6 Sites with megafossil presence in a Gredos Mountains (San Martín de la Vega del Alberche, with occurrence of pine trunks, such as that shown in the picture, dating from ca. $1200 \mathrm{cal}$. yr B.P.) and

period of increased deforestation. An increase in land use intensity during this period is probably the cause of this marked deforestation process. Finally, the last ca. $800 \mathrm{cal}$. yr в.P. are characterised by decreasing levels of fire activity, a lower representation of Ericaceae and anthropogenic indicators and a recovery of the forests, probably associated with land abandonment following the Christian Reconquest (Franco Múgica et al. 2001). These forests would be dominated once again by pines, whereas the decrease in Betula could be associated with a reduction in the surface covered by the peat bog or with selective exploitation by the local human inhabitants.

Another site from the Central Mountain Range, located in the Gredos Mountains, is the Puerto de Serranillos mire (López-Merino et al. 2009, Fig. 1). The palaeoecological record from this site shows a good correspondence between the openings of the pine forests dominating the timberline in the Gredos Mountains and the local and regional fire activity, most likely human-induced (as revealed by the pattern depicted by non-pollen palynomorphs). In the Gredos Mountains, these openings were occupied by grasslands and fire-prone shrublands, probably dominated by Cytisus oromediterraneus Rivas Mart. \& al. Therefore, highland pinewoods were probably cleared to gain new pasturelands during periods of intense human activity throughout this mountainous area. Historical evidence is in accordance with this statement, as the two periods of maximum anthropogenic disturbance (ca. 850-320 and ca. $150 \mathrm{cal}$. yr B.P. onwards) seem to be linked to significant b

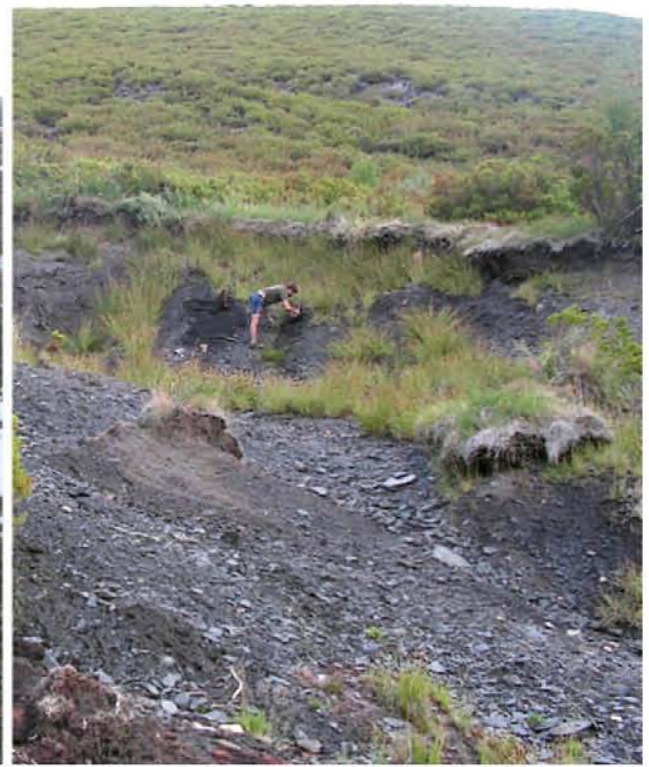

b Teleno Mountains (Pobladura de la Sierra, a mire with subfossil woods dating from ca. $3000 \mathrm{cal}$. yr B.P.)

increases in the livestock grazing these mountain pastures and the need for new open areas (López-Merino et al. 2009).

Sites with megafossil occurrence (Fig. 2; Table 2) are located in several places in the mountains of inland Iberia and generally record the existence of pines during the Holocene. In the northwestern ranges of the Teleno Mountains, data have only been reported from two sites to date, but the evidence from these sites shows that $P$. sylvestris grew at medium altitudes $(>1,300$ m.a.s.l.) in this range until at least ca. $3000 \mathrm{cal}$. yr в.P. (Morales-Molino et al. 2011, unpublished data) in areas that are now dominated by fire-prone scrub (Figs. 2, 6). In the westernmost areas of the Cantabrian Range (the Ancares and Caurel Mountains), broadleaved species such as Betula, Quercus and Ericaceae must have dominated during the mid- and late Holocene (Rubiales et al. unpublished). However, most of the macrofossil assemblages studied in this range are dominated by pines of the $P$. sylvestris/nigra group. In some cases in which well-preserved cones have been found and identified, it has been possible to detect the presence of both $P$. sylvestris (e.g. Vega de Viejos, Rubiales et al. 2008) and P. nigra, which is restricted to the eastern half of the range (e.g. Lomilla, Alcalde et al. 2001). At mid-altitude sites in areas surrounding the Iberian System (700-1,100 m. a.s.1.), impressions of cones have been identified as remains of $P$. nigra living during the early Holocene in Fuentetoba (ca. $9200 \mathrm{cal}$. yr в.P.), at the end of the mid-Holocene in Tubilla del Lago (3600-3200 cal. yr B.P.), 
Fig. 7 Comparison between different palaeoclimatic data for northern Spain based on diverse methodological approaches: red warm, light blue cold, orange dry, dark blue humid

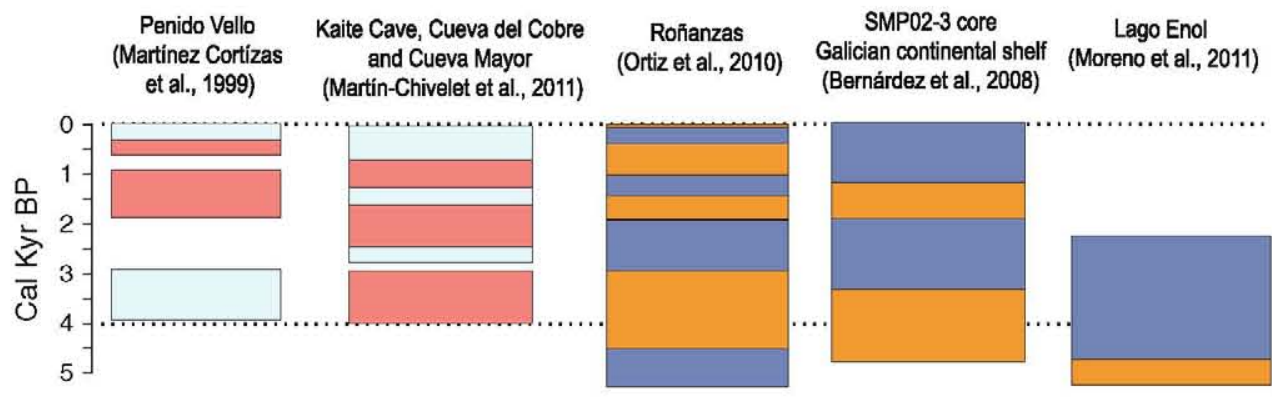

and during the late Holocene in Tubilla del Agua (ca. 2700-1300 cal. yr B.P., García-Amorena et al. 2011). These macrofossil data demonstrate a postglacial contraction of the range of this species, as shown by comparison with its present distribution (Fig. 2). In the Central Mountain Range, most of the remains that have been studied come from the Gredos Mountains (Fig. 6), which contain the highest density of sites with megafossils in the entire Iberian Peninsula (Rubiales et al. 2007, unpublished). The available data document the abundance of pinewoods in this area from the mid-Holocene to the last millennium.

Responses of highland pines to fire and anthropogenic pressure

The evidence from the pollen and plant macrofossil data shows that the greatest changes in the Holocene of the inner mountains of Iberia have occurred during the last 3,000 years, although these changes do not seem to be synchronic or to have parallel effects on the vegetation throughout the territory. Pollen-independent palaeoclimatic records are generally lacking from inland Iberia and are primarily restricted to northern, peripheral areas. Available palaeoenvironmental records based on diverse sources indicate that temperature and humidity varied during the last millennia, with alternating cold to warm and wet to dry periods (e.g. Martínez-Cortizas et al. 1999; Bernárdez et al. 2008; Ortiz et al. 2010; Martín-Chivelet et al. 2011; Fig. 7). However, the roles of climate and human activity are generally difficult to separate in the palaeoenvironmental records from ca. 4000 yr B.P. onwards due to the increasing human impact on the vegetation. References that address the responses of vegetation to climatic variations are notably scarce (e.g. Muñoz-Sobrino et al. 2005). The only multiproxy site available to date is Lago Enol, located in the Cantabrian Range (Moreno et al. 2011). The information from this site shows several climatic phases during the Holocene. These phases are accompanied by a general weak response of vegetation during the entire Holocene, up to ca. $2200 \mathrm{cal}$. yr B.P.

The diachronous pattern of vegetation change suggests that climatic changes may not have played a key role in the turnover of the vegetation. Rather, the intensification of anthropogenic activities would have been the dominant factor during this period. Essentially, the type of change that is inferred consists of an episodic decline of highland pines and/or birch and the opening of vegetation, with a clear increase in scrub (e.g. Ericaceae) and grasslands (Poaceae). The increase in Pinus in the recent past, as seen at the end of the pollen diagrams, may have several causes: (i) the disappearance of the large-scale grazing due to the abolishment of the Mesta (powerful association of cattle and sheep holders) in the 19th century; (ii) recovery after land abandonment during the Christian Reconquest; and (iii) extensive recent afforestation, especially during the 20th century.

However, important spatial variations are also evident. The sites in the northern and central Iberian System (i.e., Las Pardillas Lake and Ojos del Tremedal) show a greater persistence of highland pinewoods over time. Several factors may be responsible for this persistence. The climate of the area is strongly continental. This factor probably prevented autogenic vegetation turnover that would have resulted from competition with other potential suitable tree taxa (i.e. Fagus and/or Quercus). Through time, the area may also have been more climatically stable. Moreover, because the climate was probably more extreme (compared with that of the lowlands or other mountainous areas where conditions were milder), the intensification of human activities may have been delayed. Some of the pollen records, such as the Pelagallinas sequence, show a pattern of disturbance-recuperation that may have been coupled with pulses of low magnitude increased anthropogenic activity (very probably including the use of fire, Fig. 8).

Another group of sites (e.g. Xan de Llamas, Puerto de Serranillos, Fig. 1) experienced a severe change in vegetation cover associated with increases in the indicators of greater anthropogenic influence. The occurrence of fires seems to have played a key role in the process of change, although the origin of the disturbance is not always clear. For example, the data for the westernmost sites, in the Teleno Mountains and the Cantabrian Range, show that fires occurred, but the records of microscopic charcoal also suggest that other drivers of change may have been crucial for the pine decline (Figs. 4, 5, 7). Thus, mining activities have been an important source of disturbance in the areas 
Fig. 8 Synthetic diagram showing the vegetation dynamics recorded in the megafossil sites and pollen sequences mentioned in the text (selected for their good chronological control during the late Holocene and their microscopic and/or macroscopic charcoal data). Macro- and megafossils are represented in clusters following regional datasets. The intensity of the anthropogenic influence inferred from pollen indicators and variations in the vegetation cover is represented by black bars. Trends in regional fire activity, inferred mainly from microscopic charcoal data, are represented in red. Note that only the last $5 \mathrm{ka}$ are represented in this scheme

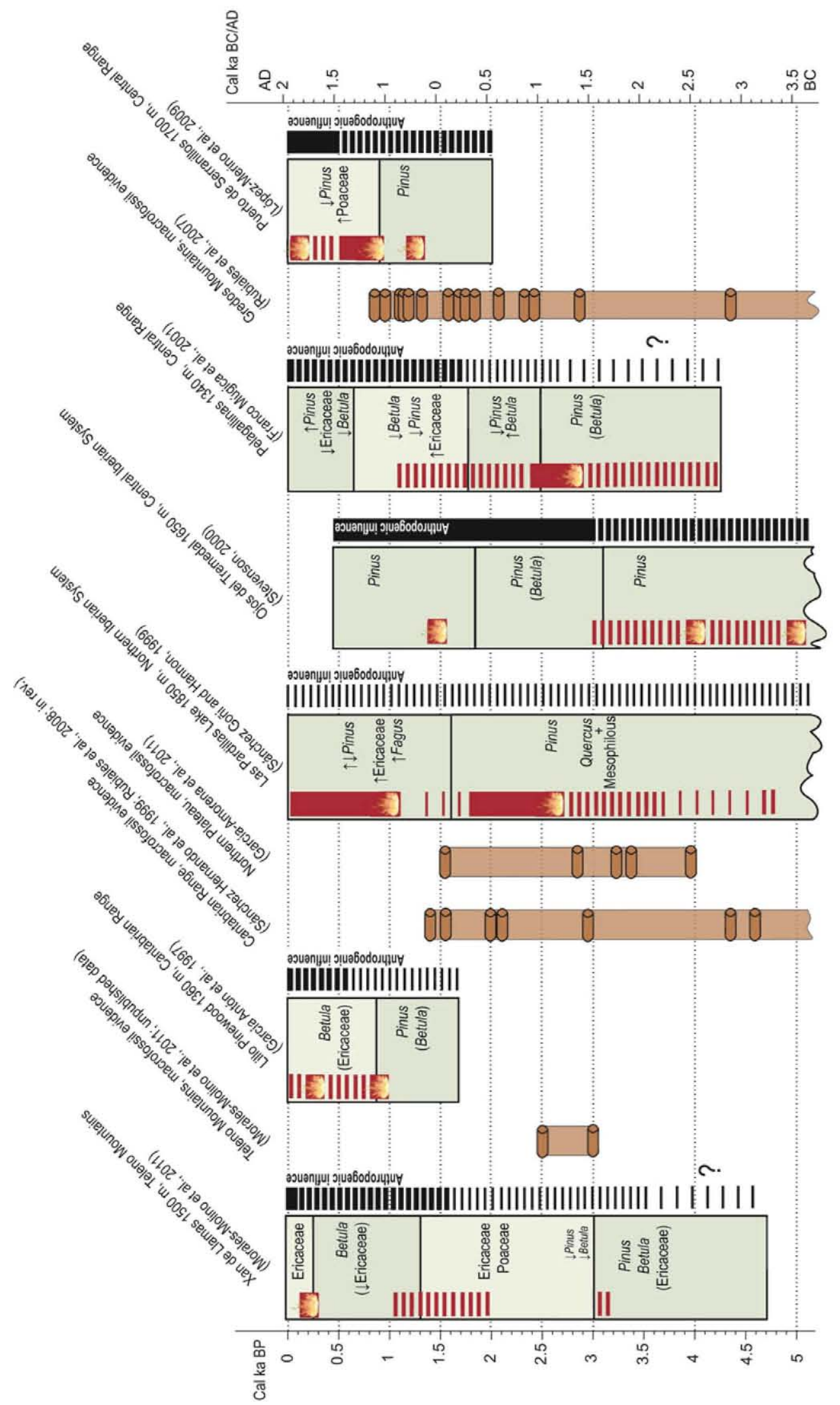


surrounding the Xan de Llamas peat bog since at least the Iron Age (Sánchez Fernández 2005), although they have been especially intense during the past two millennia (Matías 2006). Selective pine logging at the site of Lillo Pinewood has been suggested as a possible cause, together with fire, of the replacement of pines by birches at ca. 850 cal. yr B.P. (García-Antón et al. 1997). The occurrence of human selection directed towards the pines of this group has been also observed in the archaeological record and has been suggested as a cause of local extinctions during the historic period in the lowlands of the Duero basin (Rubiales et al. 2011). Finally, areas exposed to oceanic influence seem to be marginal for highland pines because of the pines' autoecological requirements (see Crawford 2005 for examples of $P$. sylvestris living in northern oceanic environments). An unsuitable habitat could aggravate the effect of disturbances and thereby prevent pine (and birch) recruitment and recolonisation.

Does fire ecology support the long-term pattern observed?

The Mediterranean Basin is currently characterised by its high-severity fire regimes and by increasingly frequent and intense wildfires (Pausas et al. 2008). In this biogeographical region, fire was an important ecological factor during the Quaternary (Carrión et al. 2003; Daniau et al. 2007). Fire could have been a relevant influence even earlier, as indicated by the large number of plant species adapted to persist and regenerate after recurrent wildfires (Pausas et al. 2004; Pausas and Verdú 2005). In fact, species showing adaptations to recurrent fires are plentiful in the Mediterranean flora. These adaptive traits include resprouting ability, soil and/or canopy seed banks and thick bark. Moreover, fire has been the primary mechanism shaping the composition of many Mediterranean plant communities under high-severity fire regimes (Verdú and Pausas 2007), and vegetation types that show resilience or resistance to fire are widespread throughout the Mediterranean Basin (Pausas et al. 2008).

Fire has long been viewed as a primary evolutionary factor for the genus Pinus (Keeley and Zedler 1998). Almost all pine species show adaptations to fire regimes (Agee 1998). Thus, fire has been considered to represent an ecological disturbance that has favoured pines throughout their geographical range (Agee 1998). On the Iberian Peninsula, the two most-widespread Mediterranean pine species $(P$. halepensis and $P$. pinaster) are early-flowering and usually show a high proportion of serotinous cones. These traits have been interpreted as adaptations to recurrent crown fires (Tapias et al. 2001, 2004). In contrast, Iberian mountain pines such as $P$. sylvestris and $P$. nigra fit the "resister strategy" (Agee 1998). Their thick bark and the absence of branches in the lower part of the crown allow them to survive low-severity fires (Tapias et al. 2001, 2004; Fernandes et al. 2008; Fulé et al. 2008). However, the lack of serotinous cones (Tapias et al. 2001, 2004), the low survival rate of the seeds after heating (Escudero et al. 1999) and their short dispersal distances (Ordóñez et al. 2006) make them very sensitive to crown fires. Empirical research on post-fire regeneration dynamics conducted in several sub-Mediterranean areas of Iberia have shown that $P$. sylvestris and $P$. nigra stands have been replaced by Quercus woodlands, shrublands or even grasslands several years or decades after the occurrence of wildfire (Retana et al. 2002; Rodrigo et al. 2004; Pérez-Cabello et al. 2010). These Iberian data on the tolerance of $P$. sylvestris to fire and on the post-fire regeneration dynamics of the species are in marked contrast with data from the boreal forests of Eurasia, where $P$. sylvestris is the most fire-tolerant tree and is, therefore, commonly favoured by recurrent fires (Agee 1998; Niklasson et al. 2010). In fact, Picea abies becomes the dominant tree species in Eurasian boreal forests if the fire frequency and intensity decrease, and this species pushes $P$. sylvestris into the background (Niklasson and Drakenberg 2001).

Nevertheless, the varying responses of $P$. sylvestris to fire regimes are understandable because of the marked differences in climate, fire regime and species pool between the Mediterranean Basin and the Eurasian boreal forests. Thus, $P$. sylvestris-dominated forests in boreal areas are commonly affected by low- to moderate-severity fire regimes characterised by ground fires, as revealed by studies conducted during the past decades on long-term fire ecology (Agee 1998) and by the frequent occurrence of individuals with multiple fire scars (Agee 1998; Niklasson and Drakenberg 2001; Niklasson et al. 2010). The humid climate and the abundance of mires in these northern coniferous forests promote a post-fire heterogeneous landscape that favours $P$. sylvestris regeneration (Agee 1998). In addition, coexisting species in the boreal forest (i.e., Picea abies) are not competitive after a fire disturbance because they are very firesensitive (Niklasson and Drakenberg 2001). In contrast, $P$. sylvestris populations on the Iberian Peninsula are subject to a Mediterranean climate with several months of summer drought, a more severe fire regime with crown fires that have spread into mountain areas during the past few decades (Pausas et al. 2008) and the presence of a significant number of trees and shrubs well-adapted to recurrent fires.

All of these data show good agreement with the palaeoecological records from the Iberian Peninsula that we have discussed in the previous section. Thus, the coupled analyses of pollen and microscopic charcoal in sedimentary sequences usually show that decreases in the Pinus pollen curves coincide with increasing trends or maxima in the macroscopic charcoal record. If the fires were, as it appears from the palaeoecological record, very intense (and/or 
probably associated with other human activities such as grazing, logging or mining), then the mountain pines would not have been able to recover their dominance in the landscape owing to their low resilience to this degree of disturbance (e.g. Xan de Llamas, Morales-Molino et al. 2011). In contrast, if the fires were indeed less intense (Fig. 9), then the resilience of the pines would have allowed them to become dominant in the landscape again (e.g. Ojos del Tremedal, Stevenson 2000). It can be hypothesised that the natural fire regimes in these mountain ranges of $\mathrm{NW}$ Iberia were characterised by low-intensity fires. The onset of intense human disturbances in these areas probably involved a change to high-intensity crown fires. These fires could have reduced the extent of the mountain pine forests.

The case of the mountains of inland central Iberia: a divergent response or a common pattern?

The highland pine species show a disjunct range in the Iberian Peninsula. They occur as marginal populations at the southernmost and westernmost edges of their range. In the areas treated by the present paper, differences seem to exist between the palaeoenvironmental history of the western and the eastern regions. These contrasting patterns are purportedly related to small differences in the history of the climate at the various locations. However, beyond the mountains of Central Iberia, the vegetation history of other Iberian areas, such as the Baetic Ranges (in the southeast) or the Pyrenees (to the north), has also been studied thoroughly.

In the Baetic ranges, the timing of the onset of intense human influence varies greatly. Fire activity seems to have been superimposed on a trend of increasing aridity during the second half of the Holocene (Gil-Romera et al. 2010). The pollen record (with microscopic charcoal) from Gádor shows that the Pinus forests have exhibited frequent threshold (but resilient) responses that have followed in succession over the last four millennia, with a final demise following fire events during the last 1,700 years (Carrión et al. 2003). The pollen diagram for Baza (Carrión et al.

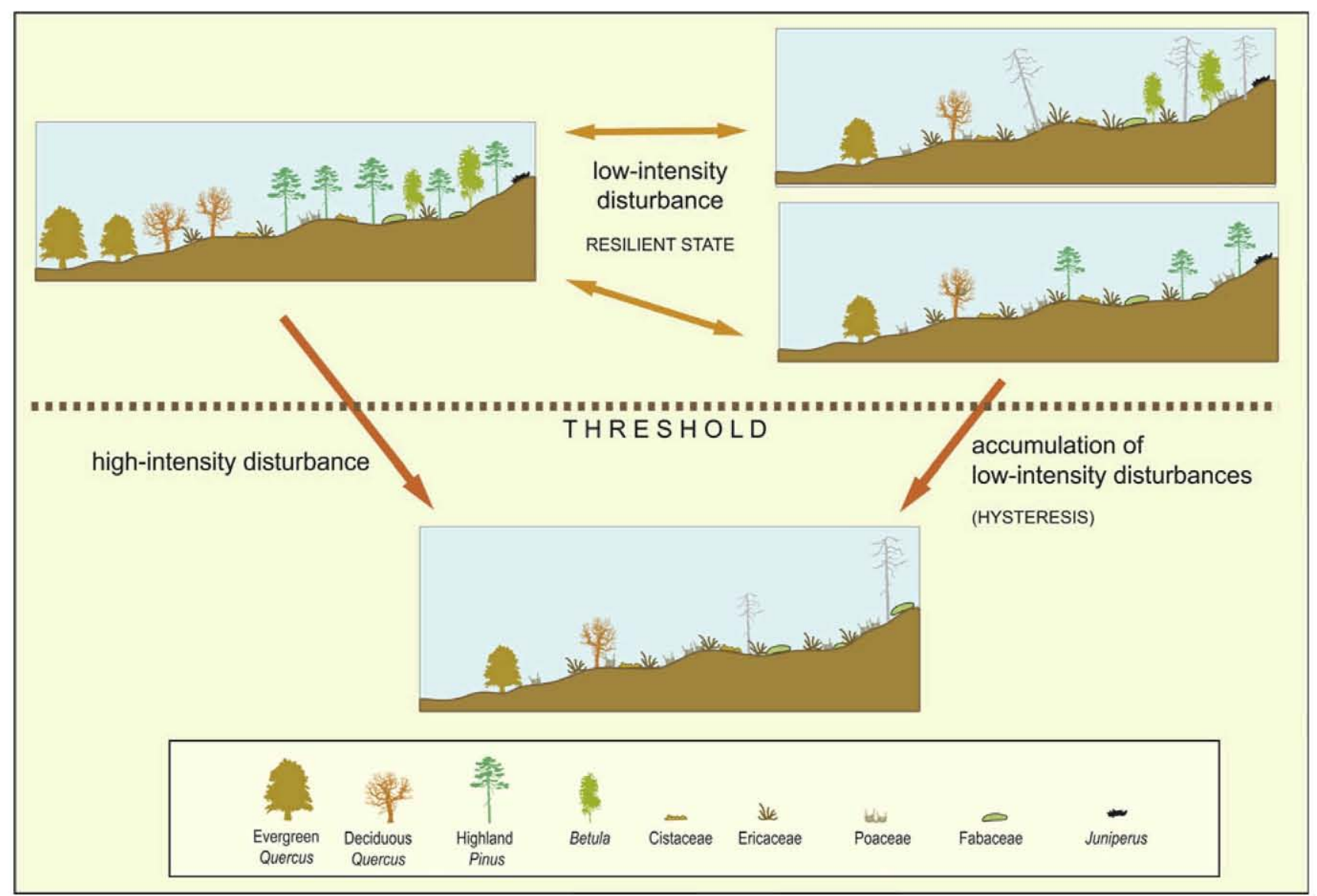

Fig. 9 Conceptual scheme of the variations in vegetation cover in response to disturbances. Highland pines may have persisted over time, even with the occurrence of low-intensity disturbances, because they were able to recolonise the area. However, after high-intensity disturbance events or after several episodes of disturbance (hysteresis effect), vegetation turnover may be irreversible. This vegetation turnover also seems to be modulated by climate because continental areas are most likely to be stable over time 
2007) furnishes another good example of the decline of mountain pinewoods. The diagram shows a continuous contraction of pinewoods, strongly linked to the development of human societies. Overall, the negative response of pines during the late Holocene seems to be well explained by the joint effects of fire occurrence and human activity in the area of interest (Gil-Romera et al. 2010).

The vegetation history of the northern slopes of the Pyrenees is well known. However, despite the very recent advances in palynological and geochemical studies, especially those covering the last 2,000 years (e.g. Ejarque et al. 2009, 2010; Pèlachs et al. 2009; Bal et al. 2011; Rull et al. 2011), knowledge of the vegetation history of the southern slopes is still limited. During the Holocene, mountain pines would have been more strongly dominant in the central part of the Pyrenees than on the flanks of the range, reflecting the continental/oceanic gradient that is also found in Iberia and in the current distribution of the forests (Costa et al. 1997; Rubiales et al. 2010). The available data link the increase in human land use and fire signals to a general tendency for the pinewoods to contract. These events generally occur at or near the onset of the second millennium B.P. (Bal et al. 2011). However, it should be noted that the patterns of change in vegetation vary greatly. This variation is dependent on several factors (e.g. altitude, productivity, historical contingencies and climate). For instance, sites at lower elevations seem to exhibit deforestation earlier than those situated at the highest altitudes (e.g. Rull et al. 2011). Phases of forest recovery are also detected in some sequences (e.g. Ejarque et al. 2009) and coincide with declines in human activities (which could correspond to climatic variations). Another interesting picture emerges from sites having fluctuating, low to medium-high percentages of Pinus (ca. 20-50\%). At these sites, the presence of stomata helps to reveal the timing of the declines and recoveries of the species (e.g. Miras et al. 2007; Ejarque et al. 2009).

The western Atlantic area of the Iberian Peninsula currently lacks natural highland pine forests, with the Gerês population as the sole exception. However, Figueiral and Carcaillet (2005) have compiled information on archaeological charcoals from central and northern Portugal identified as Pinus gr. sylvestris. These authors concluded that the group was much more widely distributed before the beginning of the historical period and suggested that fires could be responsible for this dramatic demise.

Other records of the influence of human activities and/or fire regimes on highland pine forests during the past millennia have also been reported for several western and southern European regions. In Corsica, palaeoenvironmental data suggest a succession mediated by fire occurrence at ca. 2700 cal. yr B.P. During this succession, $P$. nigra would have become locally extinct and would have been replaced by other Mediterranean tree taxa (Carcaillet et al. 1997). The palynological data from Lac de Creno (and some other sites in Corsica) correspond well to this pattern, although considerable oscillations exist during the mid-Holocene. Reille et al. (1999) also suggest that P. nigra (as well as Betula) should have been favoured by fire and clearance owing to their characteristics as pioneering species.

In the British Isles, the changes in the past distribution of $P$. sylvestris have a long history of study. The fossil record of $P$. sylvestris during the mid-Holocene indicates that the species occurred in scattered locations throughout the islands, but especially in the Scottish Highlands and western Ireland (Bennett 1984). At ca. 4400 cal. yr B.P., a synchronous contraction in the range of the species (frequently termed "the pine decline") is reported. The mechanisms responsible for that change are still not entirely clear (Bennett 1995). In certain areas, abrupt cases of range expansion and a subsequent demise have been documented (Gear and Huntley 1991). It has been hypothesised that climatic changes, browsing and anthropogenic pressures could explain the contraction of the range of the species (Bennett 2009), today confined to some isolated stands in Scotland. Fire history was proposed as a possible determinant of pine persistence, but the two phenomena seem to be unrelated (Froyd 2005; Froyd and Bennett 2006).

In the mountains of south-eastern Europe, a generalised expansion of pinewoods (including $P$. sylvestris as well as $P$. peuce and eventually $P$. mugo) at ca. $4000 \mathrm{yr}$ B.P. has been detected (Willis et al. 1998). In some areas, the increase began during the early Holocene (e.g. Stefanova and Ammann 2003; Tonkov 2003). In the mountains of Pindus, Pirin, Rhodopes and Rila, different palaeoecological records indicate the development of a well-established belt of pinewoods in the mid-Holocene. This occurrence of pinewoods is presumably linked to a climatic phase of increased precipitation. Moreover, the expansion of the pines does not seem to have been severely impacted by human land use or by fire (e.g. Bozilova and Tonkov 2000; Tonkov 2003; Tonkov and Marinova 2005; Lazarova et al. 2009).

\section{Conclusions}

The inland Iberian mountains show a characteristic and unique vegetation history during the Holocene. Highland pine forests ( $P$. sylvestris, $P$. nigra) persisted as the dominant vegetation type until the late Holocene. Major vegetation changes have occurred chiefly during the past 3,000 years in this area, and they were neither synchronous nor parallel. These observations lead us to suggest that the 
vegetation changes were driven by an intensification of human activities.

We have focussed on the palaeoecological record of the mountains of NW and central Iberia, where the most important shift in the vegetation has been the demise of highland pines. Coupled palynological and microscopic charcoal analyses provide some insights into the responses of pines to fire and the nature and magnitude of past anthropogenic disturbances. Plant macro- and megafossil occurrence completes the palaeobotanical picture by providing evidence of the local occurrence of trees and information about the species involved. Information on the current fire ecology of these species and their responses to disturbance has helped to interpret the responses observed in the palaeoecological sequences.

Palaeoecological information is still highly fragmentary, the environments under study are quite diverse and the only proxy for fire regimes is furnished by the counts of microscopic charcoal on pollen slides. Nevertheless, the data reviewed in this article are sufficient to support some ideas about the long-term responses of highland pines to fire and other disturbances. These ideas are summarised in Fig. 9. Evidently, after high-intensity disturbances (crown fires, overgrazing, logging), a threshold is crossed and pine forests are unable to recover (e.g. Xan de Llamas). Shrublands, grasslands and/or relict stands of resprouting species (e.g. Quercus, Fagus) replace the pine forests. In contrast, forest communities dominated by highland pines show some resilience to infrequent low-intensity disturbances (surface fires, moderate grazing) as is likely to have occurred in Ojos del Tremedal. If low-intensity disturbances become frequent, then the effects are similar to those of high-intensity disturbances. The populations of the more disturbance-sensitive species decline and even become locally extinct.

However, additional research is still needed to improve the reconstructions of fire history. The most recent techniques and approaches to sedimentary charcoal analysis should be used (e.g. Higuera et al. 2010). The use of highresolution reconstructions of vegetation and fire regimes will provide deeper insights into fire-climate-vegetation interactions and the role of human activities in the highly interesting area of the Iberian Peninsula, especially in connection with the late-Holocene retraction of highland pines over wide mountainous areas of northern Iberia. It is worth noting that the information derived from studies of this type has important implications for the management and conservation of forest resources throughout the area.

Acknowledgments The authors thank their colleagues from the Unit of Botany (Escuela de Ingeniería Forestal y del Medio Natural) for their help and support and to Elena Marinova and two anonymous reviewers for their comments on an earlier draft of the manuscript. We give special thanks to Carlos Morla, Nacho García-Amorena and
Elena Moreno for the input that they offered to this work. CMM holds a pre-doctoral grant from the Universidad Politécnica de Madrid. This research has been funded by the projects CGL2008-06005 BOS and CGL2009-0698 BOS (Ministerio de Educación y Ciencia, Madrid).

\section{References}

Agee JK (1998) Fire and pine ecosystems. In: Richardson DM (ed) Ecology and biogeography of Pinus. Cambridge University Press, Cambridge, pp 193-218

Alcalde C, García-Amorena I, Gómez Manzaneque F, Maldonado Ruiz J, Morla Juaristi C, Postigo Mijarra JM (2001) Estudio de los macrorrestos vegetales del yacimiento de Lomilla (Aguilar de Campoo, Palencia, España). Anales del Jardín Botánico de Madrid 59:101-112

Bal MC, Pelachs A, Perez-Obiol R, Julia R, Cunill R (2011) Fire history and human activities during the last $3300 \mathrm{cal}$ yr B.P. in Spain's Central Pyrenees: the case of the Estany de Burg. Palaeogeogr Palaeoclimatol Palaeoecol 300:179-190

Barbero M, Loisel R, Quezel P (1998) Pines of the Mediterranean Basin. In: Richardson DM (ed) Ecology and biogeography of Pinus. Cambridge University Press, Cambridge, pp 153-170

Bennett KD (1984) The post-glacial history of Pinus sylvestris in the British Isles. Quat Sci Rev 3:133-155

Bennett KD (1995) Post-glacial dynamics of pine (Pinus sylvestris L.) and pinewoods in Scotland. In: Aldhouse JR (ed) Our pinewood heritage. Forestry Commission, Royal Society for the Protection of Birds, and Scottish Natural Heritage, Farnham, Surrey, pp 23-39

Bennett KD (2009) Woodland decline in upland Scotland. Plant Ecol Divers 2:91-93

Bernárdez P, González-Álvarez R, Francés G, Prego R, Bárcena MA, Romero OE (2008) Late Holocene history of the rainfall in the NW Iberian peninsula-evidence from a marine record. J Mar Syst 72:366-382

Bozilova E, Tonkov SB (2000) Pollen from Lake Sedmo Rilsko reveals southeast European postglacial vegetation in the highest mountain area of the Balkans. New Phytol 148:315-325

Carcaillet C, Barakat HN, Panaïotis C, Loisel R (1997) Fire and late Holocene expansion of Quercus ilex and Pinus pinaster in Corsica. J Veget Sci 8:85-94

Carrión JS, Navarro C, Navarro J, Munuera M (2000) The distribution of cluster pine (Pinus pinaster) in Spain as derived from palaeoecological data: relationships with phytosociological classification. Holocene 10:243-252

Carrión JS, Sánchez-Gomez P, Mota JF, Yll R, Chain C (2003) Holocene vegetation dynamics, fire and grazing in the Sierra de Gádor, southern Spain. Holocene 13:839-849

Carrión JS, Fuentes N, González-Sampériz P, Sánchez-Quirante L, Finlayson C, Fernández S, Andrade A (2007) Holocene environmental change in a montane region of southern Europe with a long history of human settlement. Quat Sci Rev $26: 1,455-1,475$

Carrión JS, Fernández S, González-Sampériz P, Gil-Romera G, Badal E, Carrión-Marco Y, López-Merino L, López Sáez JA, Fierro E, Burjachs F (2010) Expected trends and surprises in the Lateglacial and Holocene vegetation history of the Iberian Peninsula and Balearic Islands. Rev Palaeobot Palynol 162: $458-475$

Costa M, Morla C, Sainz H (eds) (1997) Los bosques ibéricos. Una interpretación geobotánica. Planeta, Barcelona

Crawford RMM (2005) Trees by the sea: advantages and disadvantages of oceanic climates. Biol Environ Proc R Irish Acad 105:129-139 
Daniau A-L, Sánchez-Goñi MF, Beaufort L, Laggoun-Défarge F, Loutre M-F, Duprat J (2007) Dansgaard-Oeschger climatic variability revealed by fire emissions in southwestern Iberia. Quat Sci Rev 26:1,369-1,383

Ejarque A, Julià R, Riera S, Palet JM, Orengo HA, Miras Y, Gascón C (2009) Tracing the history of highland human management in the eastern Pre-Pyrenees: an interdisciplinary palaeoenvironmental study at the Pradell fen, Spain. Holocene 19:1,241-1,255

Ejarque A, Miras Y, Riera S, Palet JM, Orengo HA (2010) Testing micro-regional variability in the Holocene shaping of high mountain cultural landscapes: a palaeoenvironmental case-study in the eastern Pyrenees. J Archaeol Sci 37:1,468-1,479

Escudero A, Sanz MV, Pita JM, Pérez-García F (1999) Probability of germination after heat treatment of native Spanish pines. Annales des Sciences Forestieres 56:511-520

Fernandes PM, Vega JA, Jiménez E, Rigolot E (2008) Fire resistance of European pines. For Ecol Manag 256:246-255

Figueiral I, Carcaillet C (2005) A review of Late Pleistocene and Holocene biogeography of highland Mediterranean pines (Pinus type sylvestris) in Portugal, based on wood charcoal. Quat Sci Rev 24:2,466-2,476

Franco Múgica F, García-Antón M, Maldonado J, Morla C, Sainz H (2001) Evolución de la vegetación en el sector oriental del Sistema Central. Análisis polínico de la turbera de Pelagallinas. Anales Jard Bot Madrid 59:113-124

Froyd CA (2005) Fossil stomata reveal early pine presence in Scotland: implications for postglacial colonization analyses. Ecology 86:579-586

Froyd CA, Bennett KD (2006) Long-term ecology of native pinewood communities in East Glen Affric, Scotland. Forestry 79:279-293

Fulé PZ, Ribas M, Gutiérrez E, Vallejo R, Kaye MW (2008) Forest structure and fire history in an old Pinus nigra forest, eastern Spain. For Ecol Manag 255:1,234-1,242

García-Amorena I, Rubiales JM, Moreno E, Iglesias R, Gómez Manzaneque F (2011) New macrofossil evidence of Pinus nigra Arnold on the Northern Iberian Meseta during the Holocene. Rev Palaeobot Palynol 163:281-288

García-Antón M, Franco F, Maldonado J, Morla C, Sainz H (1997) New data concerning the evolution of the vegetation in the Lillo pinewood (León, Spain). J Biogeogr 24:929-934

García-Antón M, Franco-Múgica F, Morla-Juaristi C, MaldonadoRuiz J (2011) The biogeographical role of Pinus forest on the Northern Spanish Meseta: a new Holocene sequence. Quat Sci Rev 30:757-768

Gear AJ, Huntley B (1991) Rapid changes in the range limits of Scots Pine 4,000 years ago. Science 251:544-547

Gil-Romera G, Carrión JS, Pausas JG, Sevilla-Callejo M, Lamb HF, Fernández S, Burjachs F (2010) Holocene fire activity and vegetation response in South-Eastern Iberia. Quat Sci Rev 29:1,082-1,092

Hannon GE (1985) Late Quaternary vegetation of Sanabria marsh (north west Spain). MSc Thesis. Trinity College, Dublin

Higuera P, Gavin DG, Henne PD, Kelly RF (2010) Recent advances in the analysis and interpretation of sediment-charcoal records. PAGES News 18:57-59

Keeley JE, Zedler PH (1998) Evolution of life histories in Pinus. In: Richardson DM (ed) Ecology and biogeography of Pinus. Cambridge University Press, Cambridge, pp 219-251

Lazarova M, Tonkov S, Snowball I, Marinova E (2009) Peat-bog Begbunar (Osogovo Mountains, south-west Bulgaria): four millennia of vegetation history. Grana 48:147-179

Le Maitre DC (1998) Pines in cultivation: a global view. In: Richardson DM (ed) Ecology and biogeography of Pinus. Cambridge Univ Press, Cambridge, pp 409-431

López-Merino L, López-Sáez JA, Alba-Sánchez F, Pérez-Díaz S, Carrión JS (2009) 2,000 years of pastoralism and fire shaping high-altitude vegetation of Sierra de Gredos in central Spain. Rev Palaeobot Palynol 158:42-51

Martín-Chivelet J, Muñoz-García MB, Edward RL, Turrero MJ, Ortega AI (2011) Land surface temperature changes in Northern Iberia since $4000 \mathrm{yr} \mathrm{BP}$, based on $\delta 13 \mathrm{C}$ of speleothems. Global Planet Change. doi:10.1016/j.gloplacha.2011.02.002

Martínez-Cortizas A, Pontevedra-Pombal X, García-Rodeja E, Nóvoa-Muñoz JC, Shotyk W (1999) Mercury in a Spanish peat bog: archive of climate change and atmospheric metal deposition. Science 284:939-942

Matías R (2006) La minería aurífera romana del noroeste de Hispania: ingeniería minera y gestión de las explotaciones auríferas romanas en la sierra del Teleno (León-España). In: Nuevos elementos de ingeniería romana: III Congreso de las Obras Públicas Romanas, Astorga. Ed Junta de Castilla y León, Consejería de Cultura y Turismo, Salamanca, pp 213-263

Miras Y, Ejarque A, Riera S, Palet JM, Orengo H, Euba I (2007) Dynamique Holocène de la végétation et occupation des Pyrénées andorranes depuis le Néolithique ancient, d'après l'analyse pollinique de la tourbière de Bosc dels Estanyons (2180 m, Vall de Madriu, Andorre). CR Paleovol 6:291-300

Mirov NT (1967) The genus Pinus. The Ronald Press, New York

Morales-Molino C, García-Antón M, Morla C (2011) Late Holocene vegetation dynamics on an Atlantic-Mediterranean mountain in NW Iberia. Palaeogeogr Palaeoclimatol Palaeoecol 302:323-337

Moreno A, López-Merino L, Leira M, Marco-Barba J, GonzálezSampériz P, Valero-Garcés BL, López-Sáez JA, Santos L, Mata P, Ito E (2011) Revealing the last 13,500 years of environmental history from the multiproxy record of a mountain lake (Lago Enol, northern Iberian Peninsula). J Paleolimnol 46:327-349

Muñoz-Sobrino C, Ramil-Rego P, Gomez-Orellana L, Varela RAD (2005) Palynological data on major Holocene climatic events in NW Tberia. Boreas 34:381-400

Naveh Z (1975) The evolutionary significance of fire in the Mediterranean region. Vegetatio 29:199-208

Niklasson M, Drakenberg B (2001) A 600-year tree-ring fire history from Norra Kvills National Park, southern Sweden: implications for conservation strategies in the hemiboreal zone. Biol Conserv 101:63-71

Niklasson M, Zin E, Zielonka T, Feijen M, Korczyk AF, Churski M, Samojlik T, Jedrzejewska B, Gutowski JM, Brzeziecki B (2010) A 350-year tree-ring record from Bialowieza Primeval Forest, Poland: implications for Central European lowland fire history. J Ecol 98:1,319-1,329

Ordóñez JL, Molowny-Horas R, Retana J (2006) A model of the recruitment of Pinus nigra from unburned edges after large wildfires. Ecol Model 197:405-417

Ortiz JE, Gallego JLR, Torres T, Díaz-Bautista A, Sierra C (2010) Palaeoenvironmental reconstruction of Northern Spain during the last $8000 \mathrm{cal}$ yr BP based on the biomarker content of the Roñanzas peat bog (Asturias). Org Geochem 41:454-466

Pausas JG, Verdú M (2005) Plant persistence traits in fire-prone ecosystems of the Mediterranean basin: a phylogenetic approach. Oikos 109:196-202

Pausas JG, Bradstock RA, Keith DA, Keeley JE, GCTE Fire Network (2004) Plant functional traits in relation to fire in crown-fire ecosystems. Ecology 85:1,085-1,100

Pausas JG, Keeley JE, Verdú M (2006) Inferring differential evolutionary processes of plant persistence traits in Northern Hemisphere Mediterranean fire-prone ecosystems. J Ecol 94:31-39

Pausas JG, Llovet J, Rodrigo A, Vallejo R (2008) Are wildfires a disaster in the Mediterranean Basin? A review. Int J Wildl Fire 17:713-723

Pèlachs A, Nadal J, Soriano JM, Molina D, Cunill R (2009) Changes in the Pyrenean woodlands as a result of the intensity of human 
exploitation: 2,000 years of metallurgy in Vallferrera, northeast Iberian Peninsula. Veget Hist Archaeobot 18:403-416

Pérez-Cabello F, Ibarra P, Echeverria MT, de la Riva J (2010) Postfire land degradation of Pinus sylvestris L. woodlands after 14 years. Land Degrad Dev 21:145-160

Pérez-Obiol R, Jalut G, Julià R, Pèlachs A, Iriarte MJ, Otto T, Hernández-Beloqui B (2011) Mid-Holocene vegetation and climatic history of the Iberian Peninsula. Holocene 21:75-93

Reille M, Gamisans J, Andrieu-Ponel V, de Beaulieu JL (1999) The holocene at Lac Creno, Corsica, France: a key site for the whole island. New Phytol 141:291-307

Retana J, Espelta JM, Habrouk A, Ordóñez JL, Solà-Morales F (2002) Regeneration patterns of three Mediterranean pines and forest changes after a large wildfire in northeastern Spain. Ecoscience 9:89-97

Richardson DM, Rundel PW (1998) Ecology and biogeography of Pinus: an introduction. In: Richardson DM (ed) Ecology and biogeography of Pinus. Cambridge University Press, Cambridge, pp 3-46

Richardson DM, Rundel PW, Jackson ST, Teskey RO, Aronson J, Bytnerowicz A, Wingfield MJ, Proches S (2007) Human impacts in pine forests: past, present, and future. Ann Rev Ecol Evol Syst $38: 275-297$

Rodrigo A, Retana J, Picó FX (2004) Direct regeneration is not the only response of Mediterranean forests to large fires. Ecology 85:716-729

Rubiales JM, García-Amorena I, Génova M, Gómez Manzaneque F, Morla C (2007) The Holocene history of highland pine forests in a submediterranean mountain: the case of Gredos mountain range (Iberian Central range, Spain). Quat Sci Rev 26:1,759-1,770

Rubiales JM, García Amorena I, Álvarez SG, Gómez Manzaneque F (2008) The Late Holocene extinction of Pinus sylvestris in the West of the Cantabrian Range. J Biogeogr 35:1,840-1,850

Rubiales JM, García-Amorena I, Hernández L, Génova M, Martínez F, Gómez Manzaneque F, Morla C (2010) Late Quaternary dynamics of pinewoods in the Iberian mountains. Rev Palaeobot Palynol 162:476-491

Rubiales JM, Hernández L, Romero F, Sanz C (2011) The use of forest resources in central Iberia during the Late Iron Age. Insights from the wood charcoal analysis of Pintia, a Vaccaean oppidum. J Archaeol Sci 38:1-10

Rull V, González-Sampériz P, Corella J P, Morellón M, Giralt S (2011) Vegetation changes in the southern Pyrenean flank during the last millennium in relation to climate and human activities: the Montcortès lacustrine record. J Paleolimnol 46:387-404

Sánchez Fernández P (2005) La comarca de la Sierra del Teleno. Perspectiva geográfica, ecológica e histórica. In: Rey E, Ruiz I (eds) Seminario de restauración de áreas afectadas por grandes incendios. El caso particular del Teleno. Junta de Castilla y León, Valladolid, pp 19-31

Sánchez Hernando LJ, Gómez Manzaneque F, Masedo F, Morla C, del Nido J (1999) Identificación de macrorrestos vegetales holocenos en las cuencas altas de los ríos Porma, Curueño y Esla (León, España). Boletín de la Real Sociedad Española de Historia Natural (Secc. Biol.) 95:31-42

Sánchez-Goñi MF, Hannon G (1999) High-altitude vegetational pattern on the Iberian Mountain Chain (north-central Spain) during the Holocene. Holocene 9:39-57

Stefanova I, Ammann B (2003) Late Glacial and Holocene vegetation belts in the Pirin Mountains (southwestern Bulgaria). Holocene 13:97-107

Stevenson AC (2000) The Holocene forest history of the Montes Universales, Teruel, Spain. Holocene 10:603-610

Tapias R, Gil L, Fuentes-Utrilla P, Pardos JA (2001) Canopy seed banks in Mediterranean pines of south-eastern Spain: a comparison between Pinus halepensis Mill., $P$. pinaster Ait., $P$. nigra Arn. and $P$. pinea L. J Ecol 89:629-638

Tapias R, Climent J, Pardos JA, Gil L (2004) Life histories of Mediterranean pines. Plant Ecol 171:53-68

Tonkov S (2003) Holocene palaeovegetation in the northwestern Pirin Mountains as reconstructed from pollen analysis. Rev Palaeobot Palynol 124:51-61

Tonkov S, Marinova E (2005) Pollen and plant macrofossil analyses of radiocarbon dated mid-Holocene profiles from two subalpine lakes in the Rila Mountains, Bulgaria. Holocene 15:663-671

Verdú M, Pausas JG (2007) Fire drives phylogenetic clustering in Mediterranean Basin woody plant communities. J Ecol 95:1,316-1,323

Willis KJ, Bhagwat SA (2010) Questions of importance to the conservation of global biological diversity: answers from the past. Clim Past 6:1,139-1,162

Willis KJ, Bennett KD, Birks HJB (1998) The late Quaternary dynamics of pines in Europe. In: Richardson DM (ed) Ecology and biogeography of Pinus. Cambridge University Press, Cambridge, pp 107-121 